ISSN : 2303-1514 | E-ISSN : 2598-5949

\title{
THE INFLUENCE OF THINK PAIR SHARE TYPE OF COOPERATIVE LEARNING MODEL ON MATHEMATICS PROBLEM SOLVING ABILITY AT GRADE V ELEMENTARY SCHOOL
}

\author{
Yana Agustina ${ }^{1}$, Firman $^{2}$, Desyandri $^{3}$ \\ ${ }^{1,2,3}$ Universitas Negeri Padang, Kota Padang, Indonesia \\ ${ }^{1}$ yanaagustina08@gmail.com, ${ }^{2}$ firman@konselor.org, 3 desyandri@fip.unp.ac.id
}

\section{PENGARUH MODEL BELAJAR KOOPERATIF TIPE THINK PAIR SHARE TERHADAP KEMAMPUAN PEMECAHAN MASALAH MATEMATIS DI KELAS V SD}

\begin{tabular}{|c|c|}
\hline ARTICLE HISTORY & ABSTRACT \\
\hline $\begin{array}{l}\text { Submitted: } \\
\text { 29 Januari } 2021 \\
29^{\text {th }} \text { January } 2021\end{array}$ & 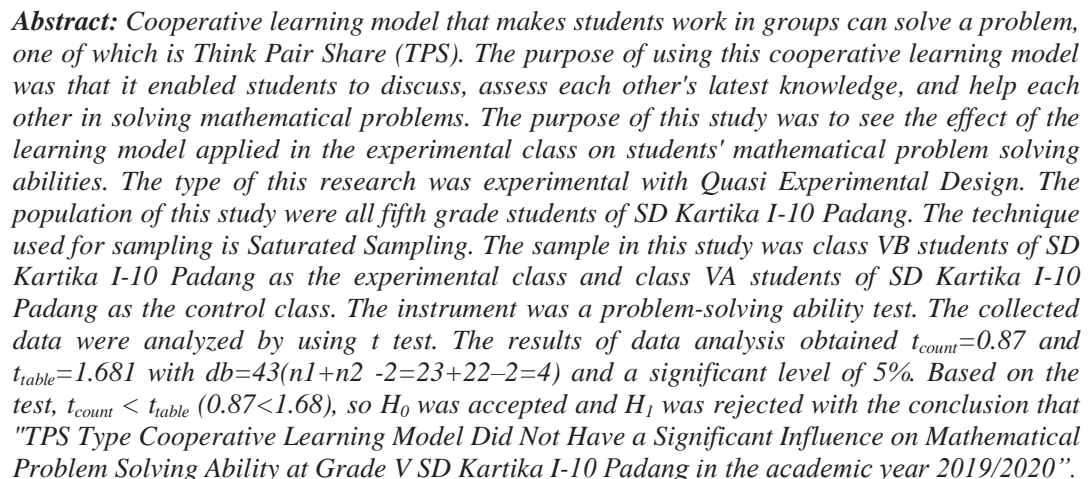 \\
\hline
\end{tabular}

Accepted:

18 Juli 2021

$18^{\text {th }}$ July 2021

Keywords: cooperative model think pair share, problem solving and learning outcomes

Abstrak: Model belajar kooperatif yang membuat siswa secara berkelompok dapat memecahkan suatu permasalahan salah satunya ialah Think Pair Share (TPS). Tujuan penggunaan model belajar kooperatif ini yaitu siswa dapat saling berdiskusi, saling menilai pengetahuan terbaru serta saling membantu untuk mengisi kelemahan masing-masing dalam menyelesaikan masalah matematis dan. Adapun tujuan penelitian, untuk melihat adanya pengaruh dari model belajar yang diberlakukan di kelas eksperimen terhadap kemampuan pemecahan masalah matematis siswa. Jenis penelitian ini adalah eksperimen dengan desain eksperimennya adalah Quasi Experimental Design. Populasi penelitian ini adalah semua siswa kelas V SD Kartika I-10 Padang. Teknik yang digunakan untuk pengambilan sampel adalah Sampling Jenuh. Sampel pada penelitian ini adalah siswa kelas V B SD Kartika I-10 Padang

Published:

27 Agustus 2021

$27^{\text {th }}$ August 2021 sebagai kelas eksperimen dan siswa kelas V A SD Kartika I-10 Padang sebagai kelas kontrol. Instrumen yang digunakan adalah tes kemampuan pemecahan masalah. Data yang terkumpul dianalisis dengan menggunakan uji $t$. Hasil analisis data menunjukkan $t_{\text {hitung }}=0.87$ dan $t_{\text {tabel }}=1,681$ dengan $d b=43\left(n_{1}+n_{2}-2=23+22-2=4\right)$ dan taraf signifikan $5 \%$. Berdasarkan pengujian $t_{\text {hitung }}<t_{\text {tabel }}(0.87<1.68)$ maka $H_{0}$ diterima dan $H_{1}$ ditolak dengan kesimpulan bahwa "Model Belajar Kooperatif Tipe TPS Tidak Memberikan Pengaruh yang Signifikan Terhadap Kemampuan Pemecahan Masalah Matematis di Kelas V SD Kartika I-10 Padang tahun ajaran 2019/2020".

Kata Kunci: model kooperatif tipe think pair share, pemecahan masalah dan hasil belajar CITATION

Agustina, Y., Firman, F., \& Desyandri, D. (2021). The Influence of Think Pair Share Type of Cooperative Learning Model on Mathematics Problem Solving Ability at Grade V Elementary School. Primary: Jurnal Pendidikan Guru Sekolah Dasar, 10 (4), 968974. DOI: http://dx.doi.org/10.33578/jpfkip.v10i4.8220 . 


\section{PENDAHULUAN}

Hasil laporan Program for Internasional Student Assesment (PISA) tahun 2015, menyatakan urutan hasil pemeringkatan Indonesia yaitu 69 dari 76 dari negara yang disurvei. Penyebabnya diantaranya adalah terjadi salah konsep dalam pembelajaran matematika terutama dalam soal cerita. Pemahaman konsep ini disebabkan dalam proses pembelajaran saat siswa dihadapkan pada soal yang membutuhkan pemecahan masalah. NCTM juga menjelaskan bahwa dalam pembelajaran matematika aspek terpentingnya yaitu pemecahan masalah (Fauzan, 2011).

Suatu bentuk proses penerimaan masalah, dimana masalah tersebut akan menjadi tantangan, adanya tantangan ini akan dapat memunculkan rasa untuk menyelesaikan masalah tersebut, itulah cara pemecahan masalah menurut (Hudojo, 2005). Jadi, dengan menerima masalah sebagai tantangan, siswa akan berusaha membuat koneksi dengan pengetahuan mereka sebelumnya yang diperlukan untuk menyelesaikan masalah, sehingga itu akan melatih siswa mengembangkan kemampuan pemecahan masalahnya. Oleh sebab itu, diharapkan siswa dalam kehidupan sehari-harinya untuk dapat mengembangkan matematikanya dan pola pikirnya (Putri et al., 2018).

Berlandaskan hal tersebut, maka peneliti melakukan observasi di SD Kartika I10 Padang pada tanggal 17 Juli 2019, 19 Juli 2019 dan 20 Juli 2019. Pada saat observasi, peneliti memberikan soal cerita matematika. Pemberian soal bertujuan untuk melihat sejauh mana siswa-siswa disana mampu menjawab dan menyelesaikan soal cerita pemecahan masalah. Soal diberikan kepada seluruh siswa kelas V B di SD Kartika I-10 Padang pada tanggal 20 Juli 2019. Adapun bentuk soalnya, seperti berikut ini:

$$
\begin{aligned}
& \text { 1. Ibu pergi ke Pasar Raya. Ibu } \\
& \text { membeli tomat } \frac{2}{4} \text { kg dan wortel } \frac{2}{8}
\end{aligned}
$$

\section{kg. Berapa kilogram berat seluruh belanjaan ibu?}

2. Bulan ini Ayah Ani menerima gaji. Jika $\frac{1}{4}$ bagian untk belanja sehari-hari. $\frac{1}{2}$ bagian untk membyar tagihan listrik. Berapa sisa gaji Ayah Ani?

Untuk soal pertama, 12 siswa menjawab dengan benar tetapi kurang tepat, karena hasil akhir pecahannya tidak disederhanakan. Untuk soal yang kedua, 23 siswa juga tidak menjawab dengan tepat. Di dalam kelas V B ini terdiri dari 23 siswa, jadi secara keseluruhan, semua siswa yang ada didalam kelas tersebut belum mampu menjawab dengan tepat dari 2 soal yang diberikan. Artinya, siswa-siswa tersebur masih rendah kemampuannya dalam memecahkan dan menyelesaikan masalah soal matematika berbentuk masalah.

Hasil wawancara dengan guru SD Kartika I-10 Padang pada tanggal 19 Juli 2019 juga menunjukkan siswa memang mengalami kesulitan dalam mempelajari matematika diantaranya siswa kurang mampu memahami masalah dan merumuskan serta menerapkan penyelesaikan masalah matematis tersebut, siswa juga tidak dilibatkan secara langsung oleh guru dalam penemuan konsep, sehingga yang aktif hanya guru saja bukan siswanya. Sebagaimana diketahui bahwa salah satu pencapaian tujuan pendidikan itu, adanya pencapaian optimal pada siswa dari segi kemampuan untuk dapat memecahkan masalah-masalah yang dihadapi (Firman, 2018).

Biasanya ide-ide matematika dapat dituangkan kepada siswa yang aktif bukan kepada siswa yang pasif. Untuk belajar, siswa itu harus berfikir aktif (Walle, 2008). Siswa yang sikapnya pasif dan tertutup akan mengurangi daya serapnya serta pemahamannya. Pemahaman merupakan hasil dari bentuk keikutsertaan siswa dalam mengerjakan matematika. Pemahaman dapat menimbulkan rasa percaya diri yang nantinya 
tumbuh dari proses pembelajaran untuk menyelesaikan masalah dalam matematika.

Kebanyakan guru berpikiran bahwa kemampuan pemecahan masalah siswa akan dapat berkembang secara otomatis, tetapi menurut Lenchner itu tidak benar, keterampilan memecahkan masalah itu juga perlu diajarkan oleh guru kepada siswa, agar dapat meningkatkan pemikiran kreatif siswa dalam menyelesaikan masalah (Fauzan, 2011).

Dari uraian masalah di atas dengan model belajar yang tepat masalah yang terjadi akan bisa teratasi. Guru perlu menerapkan model belajar yang bisa mengatasi masalah tersebut. Di sini peneliti memberikan solusi, yaitu menggunakan model pembelajaran "Cooperatif Learning". Slavin menyatakan bahwa dengan menggunakan model belajar ini bisa meningkatkan kemampuan pemecahan masalah yang bisa diberikan kepada siswa (Rusman, 2018). Salah satu variasi cooperatif learning adalah Think-Pair-Share. Arend menyatakan bahwa TPS adalah suatu bentuk cara pembelajaran yang didalamnya terdapat diskusi, sehingga siswa dapat saling membantu dalam memecahkan masalah matematis (Trianto, 2010). TPS mempunyai tiga langkah yaitu (1) Think (Berpikir), (2) Pair (Berpasangan) dan (3) Share (Berbagi).

\section{METODE PENELITIAN}

Peneliti menggunakan desain quasi experimental design (eksperimen semu). Quasi Experimental Design terdiri dari tiga tipe (Creswell, 2010). Peneliti pada penelitian ini menggunakan salah satunya yaitu tipe nonequivalent (pre-test and post-test) controlgroup design. Tipe ini menggunakan dua kelas. Kelas yang pertama yaitu kelas eksperimen dan kelas yang kedua adalah kelas kontrol. Pada awalnya, kedua kelas diberi pretest, kemudian dilakukan tiga kali proses pembelajaran. Kelompok eksperimen diberlakukan model belajar TPS, sedangkan kelompok kontrol tidak diberi perlakuan. Terakhir, kedua kelas tersebut diberikan posttest.

\section{HASIL DAN PEMBAHASAN}

Penelitian dilaksanakan sebanyak tiga kali pada tanggal 22-27 Juli 2019 di semester ganjil. Kelas V B SD Kartika I-10 Padang sebagai kelas eksperimen dan kelas V A SD Kartika I-10 Padang sebagai kelas kontrol. Materi penelitian yaitu tentang pecahan dan jam pelajaran yang sama yaitu 2 x 35 menit setiap pertemuan. Hasil penelitian diolah dengan bantuan SPSS versi 23.

Polya menyatakan ada empat langkah pemecahan masalah yaitu memahami masalah, merencanakan serta memilih berbagai strategi pemecahan masalah, melaksanakan rencana dan mereviu kembali (Fauzan, 2011). Jadi, untuk penelitian ini indikator pemecahan masalah yang peneliti gunakan sebagai berikut

1. Memahami masalah/mangajukan masalah.

2. Membuat rencana penyelesaian.

3. Melaksanakan penyelesaian/perhitungan.

4. Menyimpulkan jawaban.

Uji coba soal dilakukan pada SD Kartika I-11 Padang. Selanjutnya dilakukan validitas yang diolah dengan aplikasi Microsof Excel dan reliabilitas yang dihitung secara manual. Kemudian dilanjutkan dengan menghitung indeks kesukaran soal dan daya pembeda dengan menggunakan aplikasi Microsoft Excel, maka dari 6 butir soal pre-test yang di uji cobakan, tersisa 5 butir soal dan dari 20 butir soal post-test yang di uji cobakan, tersisa 19 butir soal. 
Tabel 1. Hasil Pre-Test KPM Matematis Siswa

\begin{tabular}{ccc} 
Statistik & $\begin{array}{c}\text { KPM } \\
\text { Kelas Eksperimen }\end{array}$ & $\begin{array}{c}\text { KPM } \\
\text { Kelas Kontrol }\end{array}$ \\
& & \\
\hline Rata-rata & 38.26 & 43.03 \\
SD & 27.23 & 22.28 \\
Varians & 741.53 & 496.46 \\
Minimum & 0 & 0 \\
Maksimum & 93.33 & 83.33 \\
N & 23 & 22 \\
\hline
\end{tabular}

Tabel $1 \mathrm{di}$ atas menyatakan hasil pretest KPM (Kemampuan Pemecahan Masalah) matematis siswa. Dimana nilai rata-rata pretest KPM kelas eksperimen agak rendah daripada kelas kontrol. Lalu dilanjutkan dengan tiga kali penelitian dikelas eksperimen dan kontrol. Kelas eksperimen saat proses belajar mengajarnya memakai media serta menggunakan LKS (Lembar Kerja Siswa) yang didalamnya sudah terdapat langkahlangkah TPS, sedangkan kelas kontrol tidak memakai media tetapi hanya menggunakan LKS biasa. Masing-masing kelas ada 3 LKS, 1 LKS diberikan setiap kali pertemuan. Setelah itu barulah, dilakukan uji soal Posttest dikedua kelas.

Tabel 2. Hasil Post-Test KPM Matematis Siswa

\begin{tabular}{ccc}
\hline \multicolumn{2}{c}{ Tabel 2. Hasil Post-Test KPM Matematis Siswa } \\
Statistik & KPM & $\begin{array}{c}\text { KPM } \\
\text { Kelas Eksperimen }\end{array}$ \\
& & \\
\hline Rata-rata & 44.35 & 38.44 \\
SD & 27.10 & 18.20 \\
Varians & 734.40 & 331.37 \\
Minimum & 0 & 0 \\
Maksimum & 91 & 78 \\
N & 23 & 22 \\
\hline
\end{tabular}

Tabel 2 menunjukkan hasil nilai posttest KPM matematis siswa. Hasil rata-rata KPM matematisnya 44.35 dan 38.44 , sehingga dari kedua kelas tersebut kelas eksperimen lebih tinggi. Selisih antara kedua kelas tersebut 5.91. Lalu, standar deviasi kelas eksperimen adalah 27.10 jauh lebih besar dibandingkan kelas kontrol yaitu 18.20, artinya nilai post-test KPM matematis siswa kelas ekperimen lebih menyebar.

Untuk uji normalitas terhadap KPM matematis siswa, peneliti menggunakan uji Shapiro-Wilk dengan bantuan SPSS 23. Pada uji normalitas tersebut didapati nilai signifikan kelas eksperimen $\mathrm{Sig}=0.273>0.05$, lalu kelas kontrol mempunyai $\mathrm{Sig}=0.218>0.05$, artinya semua data berdistribusi normal. Kemudian uji homogenitas, didapati nilai Sig $=0.052<0.05$, artinya KPM matematis siswa memiliki variansi yang homogen. Untuk hasil hipotesis, pada uji t diperoleh nilai $t_{\text {hitung }}$ $(0.87)<t_{\text {tabel }}(1.6810)$. Jika dilihat dari hasil analisis data diatas, maka terlihat bahwa KPM siswa kelas eksperimen tidak mengalami pengaruh yang signifikan. 


\section{PEMBAHASAN}

Berdasarkan analisis data yang telah didapatkan, maka terlihat bahwa tidak ada pengaruh yang signifikan antara kemampuan pemecahan masalah siswa pada kelas eksperimen yang menerapkan model pembelajaran kooperatif tipe TPS dengan siswa kelas kontrol yang menggunakan metode konvensional. Hal ini dapat dilihat dari aspek kognitif yang tergambar dari rata-rata kelas eksperimen 44.35 dan kelas kontrol 38.44 dimana selisihnya sebesar 5.91 (sangat tidak signifikan). Hasil analisis pengujian hipotesis yang diperoleh menggunakan uji-t adalah $t_{\text {hitung }}=0.87$ dan $t_{\text {tabel }}=1.68$ dimana $t_{\text {hitung }}$ lebih kecil dari pada $t_{\text {tabel. }}$.

Dari hasil analisis pengujian hipotesis tersebut maka $\mathrm{H}_{0}$ di terima dan $\mathrm{H}_{1}$ di tolak. Jadi, disimpulkan bahwa tidak terdapat perbedaan kemampuan pemecahan masalah matematika siswa yang diberi pelajaran dengan model pembelajaran kooperatif tipe TPS dengan siswa diberi pembelajaran konvensional. Artinya kemampuan pemecahan masalah matematis siswa yang diajar dengan model pembelajaran koopeeratif tipe TPS dan siswa yang diajar secara konvensional tidak mempunyai beda yang signifikan secara perhitungan statistika. Oleh karena itu dapat diartikan bahwa antara model pembelajaran koopeeratif tipe TPS dan konvensional samasama bisa dipakai untuk meningkatkan kemampuan pemecahan masalah. Antara model pembelajaran koopeeratif tipe TPS dan konvensional sama-sama juga memiliki beberapa kelebihan. Seperti yang diungkapkan oleh Trianto (2010:134) kelebihan model pembelajaran kooperatif tipe TPS diantaranya (1) Diskusi melibatkan semua siswa secara langsung dalam kegiatan belajar mengajar. (2) Setiap siswa dapat menguji tingkat pengetahuan dan penguasaan bahan pelajarannya masing-masing. (3) Diskusi dapat menumbuhkan dan mengembangkan cara berpikir dan sikap ilmiah. (4) Dengan mengajukan dan mempertahankan pendapatnya dalam diskusi diharapkan para siswa akan dapat memperoleh kepercayaan akan (kemampuan) diri sendiri. (5) Diskusinya dapat menunjang usaha- usaha pengembangan sikap sosial dan sikap demokratis para siswa.

Awalnya siswa memahami dan menyelesaikan masalah kemudian saling mendiskusikan jawaban dengan pasangan masing- masing. Selanjutnya perwakilan dari pasangan siswa mempersentasikan hasil diskusi mereka yang merupakan tahap memeriksa kembali jawaban yang dilakukan bersama-sama dengan kelompok lain. Kelompok lain bisa memberi tambahan dan tanggapan terhadap jawaban pasangan kelompok yang mempersentasikan jawabannya dalam memecahkan permasalahan matematika.

Metode konvensional salah satunya ceramah juga mempunyai kelebihan yang bisa digunakan dalam memecahkan masalah matematis seperti yang diungkapkan oleh Sri (dalam Iru \& Arihi, 2012:22) "Bahwa metode ceramah merupakan suatu cara penyajian bahan atau penyampaian bahan pelajaran secara lisan dari guru". Penyampaiannya sangat sederhana mulai dari pemberian informasi, klarifikasi, ilustrasi lalu menyimpulkan. Senada dengan Sri, Majid (2013:194) mengungkapkan "Ceramah merupakan suatu metode pembelajaran yang digunakan untuk mengembangkan proses pembelajaran melalui cara penuturan (lecture).

Nizam (2016:2) juga menyatakan data lain, yang diungkapkan oleh Program for Internasional Student Assesment (PISA), dimana PISA menyatakan hasil pemeringkatan tahun 2015 Indonesia menempati menempati urutan 69 dari 76 dari negara yang disurvei. Kelemahan-kelemahan Indonesia dalam pelaksanaan PISA diantaranya (1) Siswa sulit dalam mengerjakan soal-soal yang menuntut kemampuan pemecahan masalah, beragumentasi dan berkomunikasi, (2) Siswa meninggalkan soal yang informasinya panjang, dan cenderung tertarik pada soal yang rutin yang langsung berkaitan dengan rumus. Dari pendapat ahli diatas maka dapat dipahami bahwa siswa cenderung tertarik pada soal yang 
rutin dan agak sulit menyelesaikan soal non rutin. Soal yang peneliti gunakan semuanya merupakan soal non rutin, sehingga membuat siswa agak sulit menyelesaikan soal kemampuan pemecahan masalah baik pre-test maupun post-test dan membuat siswa sulit menyelesaiakan soal tersebut dan membuat nilai siswa menjadi rendah.

Berdasarkan uraian-uraian di atas, dapat ditarik suatu simpulan bahwa model pembelajaran kooperatif tipe TPS dan konvensional sama-sama mempengaruhi kemampuan pemecahan masalah matematis. Selain itu, peneliti menyadari bahwa masih banyak terdapat kelemahan dan kekurangan dalam pelaksanaan penelitian ini, karena tidak terlepas dari keterbatasan-keterbatasan seperti berikut ini:

1. Pelaksanaan model belajar kooperatif tipe TPS sudah dilaksanakan secara maksimal. Niilai rata-rata kelas ekperiman memang lebih tinggi dari pada kelas kontrol dengan selisih 5,9. Nilai post-test antara kelas eksperimen dan kelas kontrol sudah berdistribusi normal dan homogen, tetapi ketika melakukan uji hipotesis menggunakan uji $\mathrm{t}$ ternyata $\mathrm{t}_{\text {hitung }}<\mathrm{t}_{\text {tabel }}$ sehingga $\mathrm{H}_{0}$ diterima dan $\mathrm{H}_{1}$ ditolak.

2. Beberapa siswa lebih menyukai membuat bagian jawaban langsung, tanpa membuat bagian diketahui, ditanya, dan kesimpulan. Padahal untuk penilaian skor, penilaian dilakukan mulai dari bagian diketahui, ditanya, dijawab, dan kesimpulan. Jadi, walaupun jawaban siswa tersebut sudah benar tetapi siswa tersebut belum mendapatkan skor yang maksimal.

3. Setelah dilakukan penelitian ini ternyata siswa memang merasa sulit dalam menyelesaikan soal non rutin.

4. Materi yang diajarkan hanya satu pokok bahasan saja yaitu pecahan. Sehingga jika ingin menggunakan model ini pada materi lain, maka guru harus melakukan penelaahan terlebih dahulu mengenai kecocokan materi dengan model pembelajaran kooperatif yang akan digunakan.

\section{SIMPULAN}

Berdasarkan hasil penelitian yang peneliti laksanakan di SD Kartika I-10 Padang kelas $\mathrm{V}$ semester ganjil tahun pelajaran 2019/2020, diperoleh kesimpulan bahwa tidak terdapat perbedaan kemampuan pemecahan masalah siswa yang diajar dengan pembelajaran kooperatif tipe TPS dan konvensional. Hal ini dapat dilihat dari hasil analisis data yang menunjukkan rata-rata kelas eksperimen sebesar 44.35 dan rata-rata siswa kelas kontrol ebesar 38.44 dimana selisihnya sebesar 5.91 (sangat tidak signifikan).

Hasil uji hipotesis yang diperoleh yaitu $t_{\text {hitung }}(0.87)<t_{\text {tabel }}(1.6810)$ sehingga dapat ditarik kesimpulan bahwa "kemampuan pemecahan masalah matematis yang menggunakan model belajar kooperatif tipe Think Pair Share (TPS) tidak berpengaruh signifikan dari pembelajaran konvensional di kelas V SD Kartika I-10 Padang".

Berdasarkan kesimpulan yang telah diuraikan sebelumnya, maka dari temuan yang diperoleh dalam penelitian ini dapat dikemukakan beberapa saran, sebagai berikut:

1. Bagi guru matematika

Jika guru tertarik menerapkan model pembelajaran kooperatif tipe TPS ini, maka perlu memperhatikan hal lain yang diduga mempunyai pengaruh agar tujuan pembelajaran tercapai secara maksimal.

2. Peneliti Selanjutnya

Bagi peneliti lain yang tertarik untuk melakukan penelitian yang sama, agar menerapkan model pembelajaran kooperatif tipe TPS untuk meneliti kemampuan matematis yang lain yang dianggap terkait.

Perlu kiranya penelitian lanjutan pada pokok bahasan lain, agar penggeneralisasian kesimpulan penelitian ini dapat secara menyeluruh ditetapkan pada bidang studi matematika. Di samping itu, juga perlu penelitian lanjutan pada variabel lain yang ikut mempengaruhi hasil penelitian. 


\section{DAFTAR PUSTAKA}

Creswell, J. W. (2010). Research Design Pendekatan Kualitatif, Kuantitatif, dan Mixed. Yogyakarta: Pustaka Pelajar.

Fauzan, A. (2011). Modul 1 Evaluasi Pembelajaran Matematika. Pemecahan Masalah Matematika.

Evaluasimatematika. net: Universitas Negeri Padang.

Firman, F. (2018). Efektivitas Layanan Informasi Dengan Metode Problem Solving Terhadap Peningkatan Kontrol Diri Siswa, (2), 1-11. https://doi.org/10.31227/osf.io/rs6d7

Hudojo, H. (2005). Pengembangan Kurikulum dan Pembelajaran Matematika. Malang: UM Press.

Iru, L., \& Arihi, L. O. S. (2012). Analisis Pendekatan, Metode, Strategi, dan Model- model Pembelajaran. DIY: Multi Presindo.

Majid, A. (2013). Strategi Pembelajaran. Bandung: Rosda.

Nizam. (2016). Pembelajaran Matematika
Salah Konsep. Padang Ekspress: halaman 2.

Putri, A. R., Masniladevi, \& Desyandri. (2018). Pengaruh Penggunaan Metode Problem Solving Model Polya Terhadap Hasil Belajar Soal Cerita di Sekolah Dasar The Effect of Using Problem Solving Method with Polya Model to Students Learning Outcome About Narrative Story In Elementary School. $e$ Journal Pembelajaran Inovasi, Jurnal Ilmiah Pendidikan Dasar, 6(2), 19-32. Diambil dari http://ejournal.unp.ac.id/students/index.p hp/pgsd/article/view/5734/3012

Rusman. (2018). Model-model Pembelajaran Mengembangkan Profesionalisme Guru. Depok: Depok: Rajawali Pers.

Trianto. (2010). Mendesain Model Pembelajaran Inovatif-Progresif. Jakarta: Kencana.

Walle, J. A. Van De. (2008). Sekolah Dasar dan Menengah Matematika Pengembangan Pengajaran. Jakarta: Erlangga. 